\title{
IN VITRO CULTURE AND STUDYING THE CHEMICAL COMPOSITION OF THE ESSENTIAL OILS EXTRACTED FROM THREE SAMPLES OF ERIOCEPHALUS AFRICANUS L. PLANT IN EGYPT
}

\author{
T.A.D. Mohamed", A.M.A. Habib ${ }^{*}$, M.M. EL-Zefzafy ${ }^{* *}$ and A.I.E. Soliman ${ }^{* *}$ \\ * Ornamental Horticulture Dept., Fac. Agric., Cairo Univ., Egypt. \\ ** Medicinal Plants (Plant Tissue Culture) Dept., National Organization for Drug Control and \\ Research (NODCAR), Giza, Egypt.
}

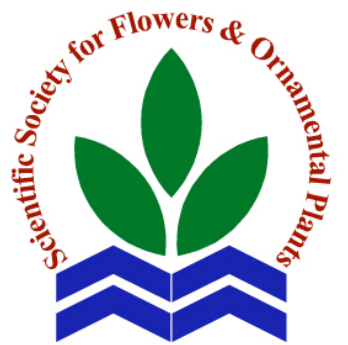

Scientific J. Flowers \& Ornamental Plants, 5(3):219-231(2018).

Received:

2/9/2018

Accepted:

$17 / 9 / 2018$

ABSTRACT: The present study aimed to establish new protocol for propagation via tissue culture techniques to observe the effect of plant growth regulators especially cytokinins, gibberellic acid and auxins with different concentrations on in vitro growth of Eriocephalus africanus L. for improving the potentiality of regeneration and secondary metabolites production and identification of the main active constituents of volatile oil by GC/MS. The results showed that, the best sterilization treatment was the shoot tip explants rinsed in a solution of clorox at $15 \%$ for 15 min was gave the highest values for survival percentage and plant strength $100 \%$ and 4.58 , respectively also $B_{5}$ medium at full strength gave the best results in the both growth measurements. BAP at $2.00 \mathrm{mg} / \mathrm{l}$ recorded the highest values in survival percentage (93.33\%), shootlet number/cluster (16.50) and shootlet strength (4.50), respectively. Using the high level from $\mathrm{GA}_{3}$ $(4.00 \mathrm{mg} / \mathrm{l})$ in medium was more effective in the elongation of shootlets. In rooting stage $B_{5}$ medium supplemented with $0.50 \mathrm{mg} / \mathrm{l}$ IBA and $0.15 \%$ active charcoal was more effective for increasing root number/explant to 8.67 and root length to $5.78 \mathrm{~cm}$. The chemical analysis for the volatile oils extracted from three samples (field, in vivo and in vitro) of Eriocephalus africanus L. by using GC/MS confirmed that, the total number of the constituents identified ranged from 30-34 compounds representing 79.67-99.41\% of the total oil contents. Artemisia ketone (17.10-30.62\%), bicyclogermacrene (4.14-15.56\%), globulol (2.17-8.30\%), allo-aromadendrene epoxide (0.51-9.00\%), caryophyllene oxide (2.85-6.76\%) and $\alpha$-pinene (3.10-4.25\%) were the main compounds.

Key words: Eriocephalus africanus $L ., \mathrm{B}_{5}$ medium, BAP, GA 3 , IBA, Active Charcoal, Volatile Oils, GC-MS and Artemisia ketone.

\section{INTRODUCTION}

The genus Eriocephalus, native from South Africa and naturalized in the Mediterranean region, is a very large and diversified member of the family Asteraceae, comprises about 32 species (Njenga et al., 2005 and Verdeguer et al., 2009). Eriocephalus africanus L. is commonly known as wild or African rosemary (Merle et al., 2007). It is the only species that has been introduced and cultivated in Egypt as an ornamental and nice smelling shrub. It is a small fast growing evergreen shrub, with green-grey foliage and snow white flowers of a distinctive fragrance that give rise to cottony seeds (Merle et al., 2007 and Salie et al., 1996). Infusions of the plant are used as 


\section{T.A.D. Mohamed et al.}

diuretic and diaphoretic, as well as to treat gastrointestinal disorders, asthma, coughs, fever and painful conditions. Moreover, this plant has also been traditionally used as medicine for the treatment of inflammation and dermal complications (Njenga and Viljoen, 2006 \& Salie et al., 1996). Plant tissue culture has been used as a biotechnological tool for the conservation and rapid micropropagation of medicinal plants and also for providing a source of secondary metabolites as well as overcoming the limitations of extracting useful metabolites from limited natural resources, significant climatic variations, risks from pathogens and is independent of soil conditions (Nagesh et al., 2010 and André et al., 2015).

Five broad classes of plant growth regulators are important in plant tissue culture: the auxins, cytokinins, gibberellins, abscisic acid and thidiazuron (Olszewski et al., 2002 \& Liu et al., 2003). Plant growth regulators are one of the most important factors affecting cell growth, differentiation and metabolite formation in plant cell and tissue cultures (Baiceanu et al., 2015). Microbial diseases rank as number one cause for almost half of the deaths in underdeveloped and tropical countries. The frequency of life-threatening infections caused by pathogenic microorganisms has increased worldwide and is becoming an important cause of morbidity and mortality in immunocompromised patients in developed countries (Al-Bari et al., 2006). Medicinal plants represent a rich source of antimicrobial agents whereas; plants are used medicinally in different countries and are a source of many potent and powerful drugs (Srivastava et al., 1996). The objective of the present study was to study the effect of $\mathrm{B}_{5}$ medium alone or supplemented with different concentrations of cytokinin, gibberellic acid and auxins on in vitro growth and development of Eriocephalus africanus L. explants. This study also aimed to evaluation of essential oils contents for three samples of Eriocephalus africanus L. (field plants, in vivo grown plants and in vitro produced plantlets).

\section{MATERIALS AND METHODS}

This work was carried out in Applied Research Center of Medicinal Plants (Tissue Culture and Phytochemistry Lab.), National Organization for Drug Control and Research (NODCAR) Giza, Egypt, and tissue culture lab of Horticulture Department, Faculty of Agriculture, Cairo University, Giza, Egypt, during the period of $2015-2018$.

All chemicals, solvents and reagents used were of analytical and pure grade. All standers were purchased from Sigma Chemical Co. (St. Lewis, USA) or ElGomhouria (Cairo, Egypt).

\section{Plant Material:}

The plant was kindly identified by Dr. Mohamed EL-Jabali of Herbarium, Orman Botanical Garden, and Ministry of Agriculture. Giza, Egypt. A voucher herbarium specimen had been deposited in the herbarium of Applied Research for Medicinal Plant Center (NODCAR).

Terminal cuttings from mother stock plants (six months old) were taken from field of the Applied Research Center of Medicinal Plants (ARCMP) and planted in controlled greenhouse at $27 \pm 1^{\circ} \mathrm{C}$ during 2-3 months and then placed in vivo outside of greenhouse (mother plant) which it considered as in vivo sample as in Photo (1) and the well in vitro plants developed (shoots with roots) as in Photo (3).

\section{Tissue culture preparation:}

Shoot tip segments of $1-1.25 \mathrm{~cm}$ in length were used as start material obtained from mother plant. The explants were kept in an anti-oxidant solution containing $100 \mathrm{mg} / \mathrm{l}$ ascorbic acid $+100 \mathrm{mg} / \mathrm{l}$ citric acid +100 $\mathrm{mg} / \mathrm{l}$ poly vinyl pyrrolidone (PVP) for one hour and washed several times by tap-water, then rinsed with a small amount of liquid soap 5\% for 5 minutes to remove the assuring of most external contamination, and rinsed again under running tap water for 30 minutes to remove all the remaining 


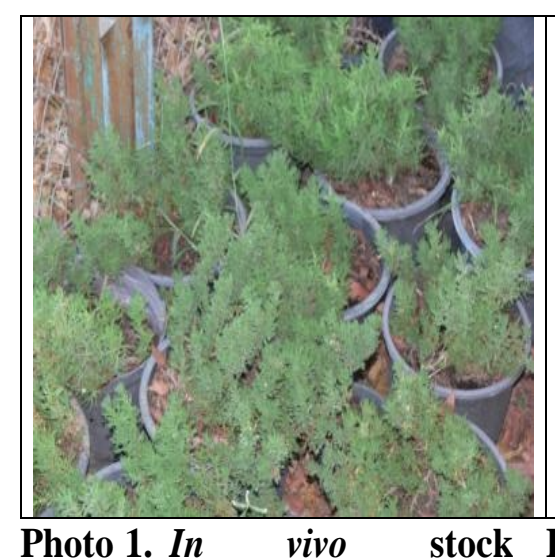

Photo 1. In vivo mother plants.

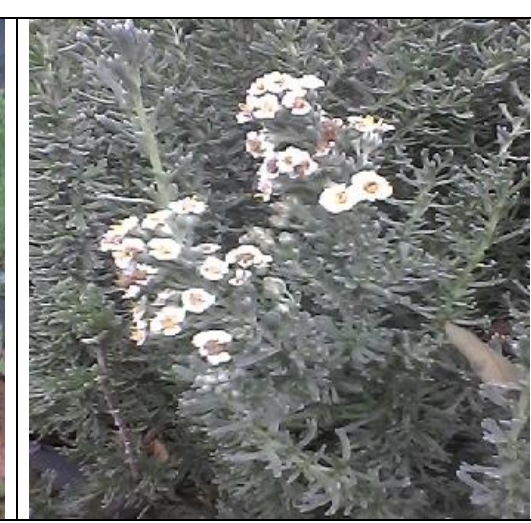

E. Photo 3. In vitro plantlets africanus $\mathrm{L}$.

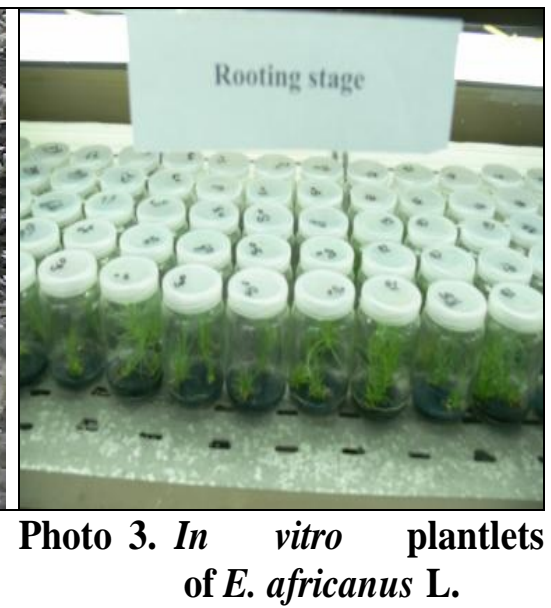

of $E$. africanus L. detergent, after that the sterilization began under aseptic condition. This procedure and all the steps of the sterilization were done under complete aseptic condition in the laminar air flow. Explants were immersed in 95\% ethanol for $2 \mathrm{sec}$, approximately $2 \mathrm{~mm}$ was removed from cut ends of the explants and they were thrice washed with a sterile distilled water for $10 \mathrm{~min}$ duration each. Explants were then kept for $10 \mathrm{~min}$ in 100 mg/l ascorbic acid+100 mg/l citric acid+100 mg/l poly vinyl pyrrolidone (PVP) solution. The sterile explants were planted in sterile jars of $350 \mathrm{ml}$ containing $40 \mathrm{ml}$ of $\mathrm{B}_{5}$ (Gamborg et al., 1968) basal medium supplemented with $30 \mathrm{~g} / \mathrm{l}$ sucrose and solidified by $5.0 \mathrm{~g} / \mathrm{l}$ agar. The essential chemicals used for preparing the media were stock solution. The $\mathrm{pH}$ value was adjusted to 5.7-5.8 by adding suitable amount of $0.1 \mathrm{~N}$ $\mathrm{HCI}$ and $0.1 \mathrm{~N} \mathrm{KOH}$ by using the $\mathrm{pH}$ meter prior to autoclaving at $1.3 \mathrm{~kg} / \mathrm{cm}^{2}$ for 20 minutes.

\section{The work designing:}

\section{In vitro micropropagation:}

a. Effect of clorox (sodium hypochlorite) concentrations and periods of sterilization on survival percentage and plant strength during surface sterilization of Eriocephalus africanus L. The shoot tip explants were cultured on $\mathrm{B}_{5}$ medium at full salt strength.

b. Effect of $B_{5}$ medium salt strength without hormones on the growth of Eriocephalus africanus L. cultured in vitro. The shoots were obtained from shoot tip explants grown on $\mathrm{B}_{5}$ medium at full salt strength were cut into stem nodes containing two axillary buds $(0.50-0.75 \mathrm{~cm})$ and recultured on $B_{5}$ full strength, $3 / 4 B_{5}, 1 / 2$ $\mathrm{B}_{5}, 1 /{ }_{4} \mathrm{~B}_{5}$ and $1 / 8 \mathrm{~B}_{5}$.

c. Effect of cytokinin, benzyl amino purine (BAP) on the growth and development of shoots. The shoots were obtained from shoot tip explants which were grown on $\mathrm{B}_{5}$ medium at full salt strength (in starting stage) and were cut into stem nodes containing two axillary buds (0.50-0.75 $\mathrm{cm})$ and recultured on different concentrations of BAP by rates of 0.0 , $0.25, \quad 0.50, \quad 1.0, \quad 2.0$ and $4.0 \mathrm{mg} / \mathrm{l}$ individually. Data were recorded after 6 weeks incubation period.

d. Effect of auxin, indole-3-butyric acid (IBA) on root formation of shoots in vitro. The plantlets were obtained from clusters grown on $B_{5}$ medium supplemented with the best concentration of $\mathrm{GA}_{3}$ at last experiment (in multiplication stage) recultured on different concentrations of indole-3-butyric acid (IBA) at rates of 0.0, $0.25,0.50,1.0$ and $2.0 \mathrm{mg} / \mathrm{l}$ individually and was added to $\mathrm{B}_{5}$ basal medium $+0.15 \%$ active charcoal. Data were recorded after 6 weeks incubation period. 


\section{Growth measurements:}

Survival \%, av. shoot number/explant, av. shoot length (cm), av. leaf number/explant, av. plant strength, rooting $\%$, av. root number/explant and av. root length $(\mathrm{cm})$. Plant strength was estimated (as score) and presented as follows according to the method described of Pattino, (1981), (a) negative growth result $=1$ (b) below average growth $=2$ (c) average growth $=3$ (d) above average growth $=4$ (e) excellent growth $=5$.

\section{Phytochemical analysis:}

\section{a. Plant material:}

1. Samples of fresh aerial parts from mother stock plants cultivated in field Farm of Applied Research Center for Medicinal Plants (ARCMP), National Organization for Drug Control and Research (NODCAR) were taken before the flowering stage and washed with a tap-water.

2. The fresh aerial parts from in vivo grown plants (mother plants) at outside the greenhouse were collected before the flowering stage and washed with a running water and was considered as in vivo sample.

3. The fresh plantlets produced in vitro after roots formation were collected and washed with a running water to remove the media and was considered as in vitro sample.

4. The age of all the plant samples was eight months. Both of them (1, 2 and 3) were then transferred to air dried room until completely dry and then crushed with mortar. The test samples (1, 2 and 3) were taken between November and January.

\section{b. Preparation of the volatile oil:}

A sample of dry plant (100 g) was subjected to hydro distillation for $3 \mathrm{~h}$ using a Clevenger-type apparatus according to the method recommended by the Egyptian Pharmacopoeia (1984). The obtained essential oils were dried over anhydrous sodium sulphate and after filtration the oil percentage in Eriocephalus africanus L. samples were determined then the samples were kept in brown bottle and saved in refrigerator at $4{ }^{\circ} \mathrm{C}$ until analysis.

\section{c. Chemical composition of the volatile oil constituents by using gas chromatography/mass spectrometer GC/MS:}

The essential oil samples (field plants, in vivo grown plants and in vitro produced plantlets) were analyzed using GC/MS in gas chromatography/mass spectrometer laboratory, National Research Center. GC/MS analysis of the essential oils was performed using a thermo trace GC 2000 (Thermo Quest, TX, USA)/MS Finnigan mat SSQ 7000 system, with the following conditions:

1. Column: DB-5, $30 \mathrm{~m}$ x $0.25 \mathrm{~mm}$ i.d., $0.25 \mu \mathrm{m}$ film

2. Carrier gas: helium (flow rate $1 \mathrm{ml} / \mathrm{min}$ )

3. Detector temperature $270{ }^{\circ} \mathrm{C}$.

4. Injector temperatures are $220^{\circ} \mathrm{C}$.

5. Oven temperature programmed:

a. Initial temperature program: $40{ }^{\circ} \mathrm{C}$ isothermal for $3 \mathrm{~min}$, then gradually increasing to $160{ }^{\circ} \mathrm{C}$ at rate of 4 ${ }^{\circ} \mathrm{C} / \mathrm{min}$, followed by $10{ }^{\circ} \mathrm{C} / \mathrm{min}$ to 280 ${ }^{\circ} \mathrm{C}$.

b. Ionization mode: EL; ion source; 70 $\mathrm{eV}$; mass range: 40-550 amu.

After stabilizing the condition, the volatile oil of the Eriocephalus africanus samples was subjected to gas chromatography coupled with mass spectrometric analysis (GC-MS) for investigation of their chemical composition. Identification of the essential oil constituents was achieved by library searched data base Willey 275 LIB and by comparing the retention indexes and mass fragmentation patterns to those of published data (Adams, 2004). The percentage composition of volatile oil components was determined by computerized peak area measurements. 


\section{Statistical analysis:}

Data of all experiments were statistically analyzed by one way randomized blocks of variance (ANOVA) using Costat 6311Win and the mean values were compared using the L.S.D method at 5\% level of significance (Gomez and Gomez, 1984).

\section{RESULTS AND DISCUSSION}

\section{In vitro micropropagation:}

a. Effect of clorox (sodium hypochlorite) concentrations and periods of sterilization on survival percentage and plant strength of shoot tip explants:

The presented data in Table (1) showed that, using $15 \%$ clorox for 15 min seemed to be the most suitable treatment for survival percentage and plant strength of shoot tip explants (100\% and 4.58, respectively) while the lowest survival percentage and plant strength were recorded for $20 \%$ clorox for 15 $\min$ (84.62\% and 2.17, respectively).

These results were found to be in agreement with those of Yassien et al. (2016) who sterilized the explants shoot tips of Artemisia abrotanum L. with a $20 \%(\mathrm{w} / \mathrm{v})$ sodium hypochlorite $(\mathrm{NaOCl})$ for $15 \mathrm{~min}$. Madzikane-Mlungwana et al. (2017) observed that the shoot tips of Eriocephalus africanus were surface decontaminated in a laminar flow bench using $70 \%$ ethanol (v/v) for $60 \mathrm{~s}$ followed by sodium hypochlorite ( $\mathrm{NaOCl} ; 2.00 \%$ or $3.50 \%$ ) for either 10 or 20 min.

\section{b. Effect of $B_{5}$ medium salt strength on the growth of Eriocephalus africanus $\mathrm{L}$. stem nodes:}

The effects of $\mathrm{B}_{5}$ medium on growth of Eriocephalus africanus L. as shoot and root formation parameters as shown in Table (2) the highest significant values were recorded with $\mathrm{B}_{5}$ full strength as follows; survival percentage $100 \%$, shoot number 5.40 , shoot length $3.00 \mathrm{~cm}$, leaf number 8.66 , shoot strength 4.50 , rooting percentage $60 \%$, root number 3.67 and root length $3.74 \mathrm{~cm}$ comparing with other strength medium.
Whereas, one eighth strength of the medium recorded the lowest values of the parameters; survival percentage $57.14 \%$, shoot number 1.00 , shoot length $0.63 \mathrm{~cm}$, leaf number 3.83 and shoot strength 2.27 also the same treatment had non-significant effect on rooting percentage, root number and root length.

The present results were in harmony with those of Soliman, (2011) who observed that the highest significant values were recorded with full $B_{5}$ and $1 / 2 B_{5}$ medium salt strength for all parameters when culturing the shoot tip explants of Rosmarinus officinalis L. var. ternifolius. Monfort et al. (2018) found that the $\mathrm{B}_{5}$ medium full strength had significant effect on the growth and development for the shootlets produced from nodal segments of Ocimum basilicum where recorded the highest values of leaf number (20), shoot height $(4.54 \mathrm{~cm})$, root number (6) and root length $(2.84 \mathrm{~cm})$ after 40 days from culturing.

c. Effect of different concentrations of benzyl amino purine (BAP) on the growth and development of explants cultured on $B_{5}$ medium:

The presented data in Table (3) showed that, $\mathrm{B}_{5}$ medium supplemented with the high concentrations from BAP (2.0 and $4.0 \mathrm{mg} / \mathrm{l}$ ) gave the highest value of survival percentage (93.33\%) for each, while $\mathrm{B}_{5}$ medium (control) and $\mathrm{B}_{5}$ medium supplemented with the low concentration from BAP at $0.25 \mathrm{mg} / \mathrm{l}$ gave the lowest value of $66.67 \%$. Shootlet number/cluster and shootlet strength were significantly affected by the concentration of $2.0 \mathrm{mg} / \mathrm{l} \mathrm{BAP} \mathrm{(16.50} \mathrm{and} \mathrm{4.50,} \mathrm{respectively),}$ whereas the $\mathrm{B}_{5}$ medium (control) gave the smallest number (1.70) and the shootlet strength recorded the smallest value (3.00) with increase the BAP concentration from 0.25 to $1.0 \mathrm{mg} / \mathrm{l}$. $\mathrm{B}_{5}$ medium (control) without any growth regulators recorded the highest values for shootlet length and leaf number (1.94 cm and 9.22, respectively), while the high concentration of BAP (4.0 $\mathrm{mg} / \mathrm{l})$ recorded the lowest values $(0.32 \mathrm{~cm}$ and 4.97, respectively). 
T.A.D. Mohamed et al.

Table 1. Effect of clorox (sodium hypochlorite) concentrations and periods of sterilization on survival percentage and plant strength of shoot tip explants after 6 weeks from culturing.

\begin{tabular}{|c|c|c|c|c|}
\hline \multirow[b]{2}{*}{$\begin{array}{c}\text { Time of } \\
\text { sterilization }\end{array}$} & \multicolumn{4}{|c|}{ Concentrations of clorox (sodium hypochlorite) } \\
\hline & $\begin{array}{c}15 \% \text { clorox } \\
(0.79 \% \text { NaOCl) }\end{array}$ & $\begin{array}{c}20 \% \text { clorox } \\
(1.00 \% \text { NaOC })\end{array}$ & $\begin{array}{c}15 \% \text { clorox } \\
(0.79 \% \text { NaOC })\end{array}$ & $\begin{array}{c}20 \% \text { clorox } \\
(1.00 \% \text { NaOC })\end{array}$ \\
\hline & \multicolumn{2}{|c|}{ Survival $\%$} & \multicolumn{2}{|c|}{ Av. plant strength } \\
\hline $10 \mathrm{~min}$ & 85.71 & 92.31 & $3.92 \mathrm{~B}$ & $2.42 \mathrm{C}$ \\
\hline $15 \mathrm{~min}$ & 100 & 84.62 & $4.58 \mathrm{~A}$ & $2.17 \mathrm{D}$ \\
\hline L.S.D at $5 \%$ & - & - & \multicolumn{2}{|c|}{0.2308} \\
\hline
\end{tabular}

Table 2. Effect of $\mathbf{B}_{5}$ medium salt strength on the growth of Eriocephalus africanus $\mathbf{L}$. stem nodes cultured in vitro after 6 weeks from culturing.

\begin{tabular}{ccccccccc}
\hline $\begin{array}{c}\text { Treatment } \\
\text { B } \text { salt strength }\end{array}$ & $\begin{array}{c}\text { Survival } \\
\text { \% }\end{array}$ & $\begin{array}{c}\text { Av. shoot } \\
\text { number }\end{array}$ & $\begin{array}{c}\text { Av. shoot } \\
\text { length } \mathbf{( c m})\end{array}$ & $\begin{array}{c}\text { Av. leaf } \\
\text { number }\end{array}$ & $\begin{array}{c}\text { Av. shoot } \\
\text { strength }\end{array}$ & $\begin{array}{c}\text { Rooting } \\
\%\end{array}$ & $\begin{array}{c}\text { Av. root } \\
\text { number }\end{array}$ & $\begin{array}{c}\text { Av. root } \\
\text { length } \\
\text { (cm) }\end{array}$ \\
\hline Full & 100 & $5.40 \mathrm{~A}$ & $3.00 \mathrm{~A}$ & $8.66 \mathrm{~A}$ & $4.50 \mathrm{~A}$ & 60.00 & $3.67 \mathrm{~A}$ & $3.74 \mathrm{~A}$ \\
$\mathbf{3 / 4}$ & 77.80 & $3.06 \mathrm{C}$ & $2.26 \mathrm{C}$ & $8.04 \mathrm{C}$ & $3.01 \mathrm{C}$ & 25.00 & $1.37 \mathrm{C}$ & $1.17 \mathrm{C}$ \\
$\mathbf{1} / \mathbf{2}$ & 88.90 & $3.75 \mathrm{~B}$ & $2.62 \mathrm{~B}$ & $8.33 \mathrm{~B}$ & $3.83 \mathrm{~B}$ & 50.00 & $3.00 \mathrm{~B}$ & $1.83 \mathrm{~B}$ \\
$\mathbf{1} / \mathbf{4}$ & 71.14 & $2.17 \mathrm{D}$ & $1.30 \mathrm{D}$ & $5.10 \mathrm{D}$ & $2.67 \mathrm{D}$ & 33.33 & $1.00 \mathrm{D}$ & $0.57 \mathrm{D}$ \\
$\mathbf{1 / 8}$ & 57.14 & $1.00 \mathrm{E}$ & $0.63 \mathrm{E}$ & $3.83 \mathrm{E}$ & $2.27 \mathrm{E}$ & 0.00 & $0.00 \mathrm{E}$ & $0.00 \mathrm{E}$ \\
L.S.D at 5\% & - & 0.6447 & 0.3162 & 0.2694 & 0.3357 & - & 0.3457 & 0.5558 \\
\hline
\end{tabular}

Table 3. Effect of different concentrations of benzyl amino purine (BAP) on the growth and development of explants cultured on $B_{5}$ medium.

\begin{tabular}{cccccc}
\hline $\begin{array}{c}\text { Treatment } \\
\text { (BAP mg/l) }\end{array}$ & $\begin{array}{c}\text { Survival } \\
\text { \% }\end{array}$ & $\begin{array}{c}\text { Av. shootlet } \\
\text { number/cluster }\end{array}$ & $\begin{array}{c}\text { Av. shootlet } \\
\text { length } \mathbf{( c m )}\end{array}$ & Av. leaf number & $\begin{array}{c}\text { Av. shootlet } \\
\text { strength }\end{array}$ \\
\hline B $_{\mathbf{5}}$ Control & 66.67 & $1.70 \mathrm{~F}$ & $1.94 \mathrm{~A}$ & $9.22 \mathrm{~A}$ & $3.40 \mathrm{C}$ \\
$\mathbf{0 . 2 5}$ & 66.67 & $6.70 \mathrm{E}$ & $1.23 \mathrm{~B}$ & $8.30 \mathrm{~B}$ & $3.00 \mathrm{D}$ \\
$\mathbf{0 . 5 0}$ & 80.00 & $9.33 \mathrm{D}$ & $0.90 \mathrm{C}$ & $6.42 \mathrm{D}$ & $3.00 \mathrm{D}$ \\
$\mathbf{1 . 0 0}$ & 83.33 & $9.83 \mathrm{C}$ & $0.53 \mathrm{E}$ & $5.96 \mathrm{E}$ & $3.00 \mathrm{D}$ \\
$\mathbf{2 . 0 0}$ & 93.33 & $16.50 \mathrm{~A}$ & $0.74 \mathrm{D}$ & $7.11 \mathrm{C}$ & $4.50 \mathrm{~A}$ \\
$\mathbf{4 . 0 0}$ & 93.33 & $14.00 \mathrm{~B}$ & $0.32 \mathrm{~F}$ & $4.97 \mathrm{~F}$ & $4.00 \mathrm{~B}$ \\
L.S.D at 5\% & - & 0.4710 & 0.1970 & 0.4450 & 0.3510 \\
\hline
\end{tabular}

These results were in agreement with those of El-Tarras et al. (2015) who demonstrated for Ficus palmata Forsk, that the maximum average number of multiplied shoots (3.25) was produced on $2.00 \mathrm{mg} / \mathrm{l}$ BAP and Abd EL-Hamied (2016) who found on the in vitro growth of Artemisia abrotanum L. that the shoots number was 35.65 shoots/explant at $2.00 \mathrm{mg} / \mathrm{l} \mathrm{BAP.}$ d. Effect of auxin indole-3-butyric acid (IBA) on rooting and growth of Eriocephalus africanus L. shoots in vitro cultured on $B_{5}$ medium:

For the effect of different concentrations of auxin (IBA), data are shown in Table (4). The best survival and rooting percentage (100\%) were recorded with $\mathrm{B}_{5}$ medium (control) without hormones but the 
Table 4. Effect of different concentrations of auxin indole-3-butyric acid (IBA) on rooting and growth of Eriocephalus africanus $\mathrm{L}$. shoots cultured in vitro after 6 weeks from culturing.

\begin{tabular}{ccccccc}
\hline $\begin{array}{c}\text { Treatment } \\
\text { (IBA mg/l) }\end{array}$ & Survival \% & $\begin{array}{c}\text { Av. shoot length } \\
\text { cm/explant }\end{array}$ & Rooting \% & $\begin{array}{c}\text { Av. root } \\
\text { number/ } \\
\text { explant }\end{array}$ & $\begin{array}{c}\text { Av. root length } \\
\text { cm/explant }\end{array}$ & $\begin{array}{c}\text { Av. plant } \\
\text { strength }\end{array}$ \\
\hline $\mathbf{B}_{\mathbf{5}}$ Control & 100 & 3.27 & 82.86 & 3.78 & 5.08 & 2.56 \\
$\mathbf{0 . 2 5}$ & 80 & 2.98 & 70 & 5.75 & 3.51 & 2.63 \\
$\mathbf{0 . 5}$ & 100 & 5.35 & 100 & 8.67 & 5.78 & 4.00 \\
$\mathbf{1 . 0}$ & 100 & 4.29 & 100 & 5.33 & 4.76 & 2.87 \\
$\mathbf{2 . 0}$ & 40 & 4.58 & 40 & 5.76 & 2.27 & 3.30 \\
L.S.D at 5\% & - & 0.2750 & - & 0.4035 & 0.4601 & 0.2317 \\
\hline
\end{tabular}

maximum concentration of IBA at $2.0 \mathrm{mg} / \mathrm{l}$ recorded the lowest values of each survival percentage (40\%), rooting percentage (40\%) and root length $(2.27 \mathrm{~cm} /$ explant $)$. However, the concentration $0.50 \mathrm{mg} / \mathrm{l}$ IBA recorded the highest values of shoot length $\mathrm{cm}$, root number, root length $\mathrm{cm} /$ explant and plant strength $(4.58 \mathrm{~cm}, 8.67,5.78 \mathrm{~cm}$ and 4.0 , respectively) compared with $B_{5}$ medium (control) without hormones and minimum concentration of IBA at $0.25 \mathrm{mg} / \mathrm{l}$ which recorded the lowest values of plant strength (2.56 and 2.63, respectively) as well as the lowest value of shoot number/explant (1.91) recorded with $0.5 \mathrm{mg} / \mathrm{l} \mathrm{IBA}$.

These results agreed with those of Gopinath et al. (2014) who found that, the well developed in vitro shoots of Artemisia annua L. were transferred on rooting media supplemented with various concentration of IBA $(1.00 \mathrm{mg} / \mathrm{l})$ showed efficient root induction and further development of healthy root and then acclimatized and successfully established in field with $85 \%$ of survival. Labade et al. (2016) studied the effect of different concentrations of IBA on the rooting of Chrysanthemum morifolium shoots raised from nodal segments. The result showed superiority of $1 / 2 \mathrm{MS}+0.20 \mathrm{mg} / \mathrm{l}$ IBA as compared to all the other treatments as it produced significantly maximum number of roots per explant $(11.80 \pm 0.75)$ and largest roots $(9 \pm 0.19 \mathrm{~cm})$ and survival rate was $90 \%$ as IBA is considered as the most efficient auxins in root induction and development.

\section{Phytochemical analysis: Chemical composition of the volatile oil constituents by using gas chromatography/mass spectrometer GC/MS:}

A comparative study was carried out between three samples of Eriocephalus africanus L. (field plants, in vivo grown plants and in vitro produced plantlets). The samples were analyzed by GC-MS, the qualitative and quantitative composition of the volatile oils constituents are shown in Tables (5 \& 6) and illustrated in Figures (1\&2\&3). Thirty to thirty-four compounds were identified, accounting for 79.67$99.41 \%$ of the total oil contents. Essential oils for the three samples were rich in oxygenated compounds, 9 oxygenated monoterpenes representing $26.53 \%$ at in vitro plantlets, 8 oxygenated monoterpenes with percentage of $40.31 \%$ at in vivo plants and 8 oxygenated monoterpenes representing $41.30 \%$ in field plants, and 11 oxygenated sesquiterpenes with percentage of $15.05 \%$ in field plants, $28.72 \%$ at in vitro plantlets and $35.36 \%$ at in vivo plants.

The highest percentage of the main constituents were Artemisia ketone 30.62\% which is considered as the characteristic compound of Eriocephalus africanus L. and artemisia alcohol $4.61 \%$ in field plants and also 1,8 -cineole $3.93 \%$, globulol $8.30 \%$, allo- 
T.A.D. Mohamed et al.

Table 5. Constituents of the essential oils from three samples of Eriocephalus africanus L. by GC-MS analysis.

\begin{tabular}{|c|c|c|c|c|c|}
\hline \multirow{2}{*}{$\begin{array}{c}\text { Peak } \\
\text { No. }\end{array}$} & \multirow{2}{*}{ Name of compound } & \multirow[b]{2}{*}{ KI } & \multicolumn{3}{|c|}{ Percentage of compound \% } \\
\hline & & & Field plants & In vivo plants & In vitro plantlets \\
\hline & Monoterpene hydrocarbons & & & & \\
\hline 1 & a-Pinene & 939 & 4.25 & 3.64 & 3.10 \\
\hline 2 & Camphene & 954 & 0.20 & 1.60 & 1.00 \\
\hline \multirow[t]{2}{*}{3} & $\beta$ - Ppinene & 979 & 1.50 & 1.00 & 0.85 \\
\hline & Oxygenated monoterpenes & & & & \\
\hline 4 & Yomogi alcohol & 999 & 0.83 & 0.87 & 0.66 \\
\hline 5 & 1,8-Cineole & 1031 & 0.33 & 3.93 & 1.60 \\
\hline 6 & Artemisia ketone & 1062 & 30.62 & 30.31 & 17.10 \\
\hline 7 & Artemesia alcohol & 1084 & 4.61 & 1.52 & 1.64 \\
\hline 8 & Trans-pinocarveol & 1139 & 1.21 & 0.40 & 1.00 \\
\hline 9 & Camphor & 1146 & 0.26 & 2.31 & 3.03 \\
\hline 10 & Pinocarvone & 1165 & 1.50 & 0.64 & 0.90 \\
\hline \multirow[t]{2}{*}{11} & Myrtenol & 1196 & 0.74 & 0.33 & 0.60 \\
\hline & Sesquiterpene hydrocarbons & & & & \\
\hline 12 & a-Cubebene & 1351 & 1.50 & 0.23 & 0.60 \\
\hline \multirow[t]{2}{*}{13} & $\alpha$-Copaene & 1377 & 2.10 & - & - \\
\hline & Oxygenated monoterpenes & & & & \\
\hline \multirow[t]{2}{*}{14} & Geranyl acetate & 1381 & 1.20 & - & - \\
\hline & Sesquiterpene hydrocarbons & & & & \\
\hline 15 & Caryophyllene $<$ E $>$ & 1419 & 2.50 & 0.31 & 0.40 \\
\hline 16 & $\alpha$-Humulene & 1455 & 1.01 & - & - \\
\hline 17 & Alloaromadendrene & 1460 & 0.57 & - & - \\
\hline 18 & cis- $\beta$-Guaiene & 1493 & 0.36 & 0.33 & 0.85 \\
\hline 19 & $\alpha$-Selinene & 1498 & 2.44 & 1.04 & 0.47 \\
\hline 20 & $\beta$-Selinene & 1490 & 1.52 & 0.53 & 0.43 \\
\hline 21 & Bicyclogermacrene & 1500 & 4.14 & 13.82 & 15.56 \\
\hline \multirow[t]{2}{*}{22} & Selina-3,7(11)-diene & 1547 & 2.32 & 0.34 & 0.36 \\
\hline & Oxygenated sesquiterpenes & & & & \\
\hline 23 & Spathulenol & 1578 & 1.30 & 1.26 & 0.44 \\
\hline 24 & Caryophyllene oxide & 1583 & 2.85 & 5.23 & 6.76 \\
\hline 25 & Globulol & 1585 & 2.17 & 8.30 & 5.64 \\
\hline 26 & $\beta$-Copaen-4a-ol & 1591 & 1.30 & 0.75 & 0.44 \\
\hline 27 & Veridiflorol & 1593 & 0.80 & 1.06 & 1.36 \\
\hline 28 & Guaiol & 1601 & 0.37 & 1.37 & 0.40 \\
\hline 29 & 10-epi- $\gamma$-Eudesmol & 1624 & 1.93 & 0.90 & 1.42 \\
\hline 30 & Allo-Aromadendrene epoxide & 1641 & 0.51 & 9.00 & 7.00 \\
\hline 31 & $\beta$ - Eudesmol & 1651 & 1.52 & 5.97 & 2.36 \\
\hline 32 & $\alpha$-Cadinol & 1654 & 1.50 & 1.21 & 0.60 \\
\hline \multirow[t]{2}{*}{33} & Eudesm-7(11)-en-4-ol & 1700 & 0.80 & 0.31 & 2.30 \\
\hline & Oxygenated diterpenes & & & & \\
\hline 34 & Phytol & 1943 & 0.35 & 0.90 & 0.80 \\
\hline
\end{tabular}

KI: Kovats retention indices according to Adams (2004). 
Table 6. Percentage of different group constituents of the essential oils of samples of Eriocephalus africanus $\mathbf{L}$.

\begin{tabular}{lccc}
\hline \multicolumn{1}{c}{ Group constituents } & \multicolumn{3}{c}{ Percentage of group constituents } \\
& Field & In vivo & In vitro \\
\hline Hydrocarbons & & & \\
$\quad$ Monoterpene hydrocarbons & 5.95 & 6.24 & 4.95 \\
$\quad$ Sesquiterpene hydrocarbons & 18.46 & 16.60 & 18.67 \\
$\quad$ Total hydrocarbons & 24.41 & 22.84 & 23.62 \\
Oxygenated compounds & & & \\
$\quad$ Oxygenated monoterpenes & 41.30 & 40.31 & 26.53 \\
Oxygenated sesquiterpenes & 15.05 & 35.36 & 28.72 \\
Oxygenated diterpenes & 0.35 & 0.90 & 0.80 \\
$\quad$ Total oxygenated compounds & 56.70 & 76.57 & 56.05 \\
Total oil composition \% & 81.11 & 99.41 & 79.67 \\
Total identified compounds & 34 compounds & 30 compounds & 30 compounds \\
\hline
\end{tabular}

RT: $0.00-68.01$

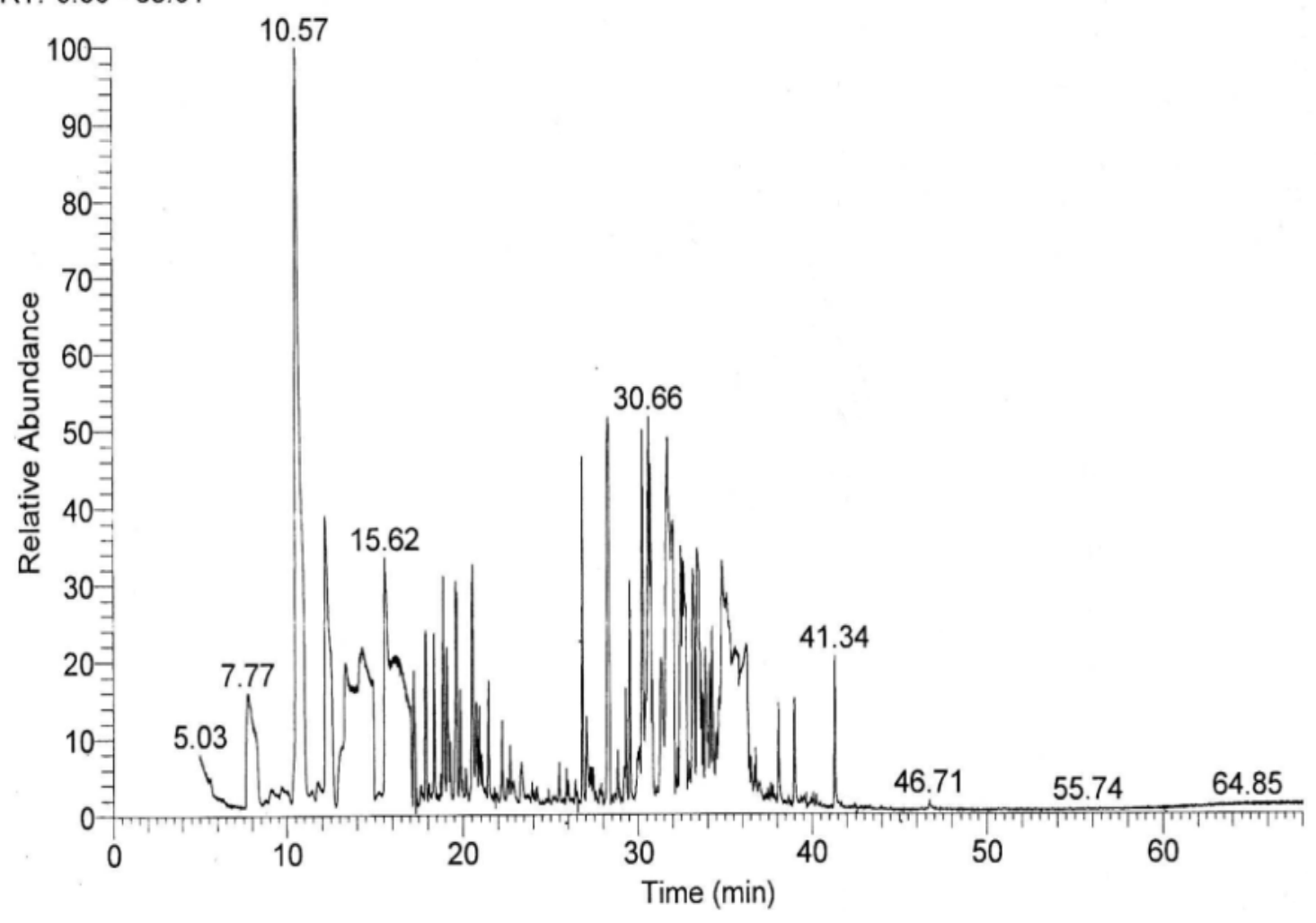

Figure 1. The chromatogram of GC/MS analysis of the essential oil of Eriocephalus africanus $\mathrm{L}$. in field. 
T.A.D. Mohamed et al.

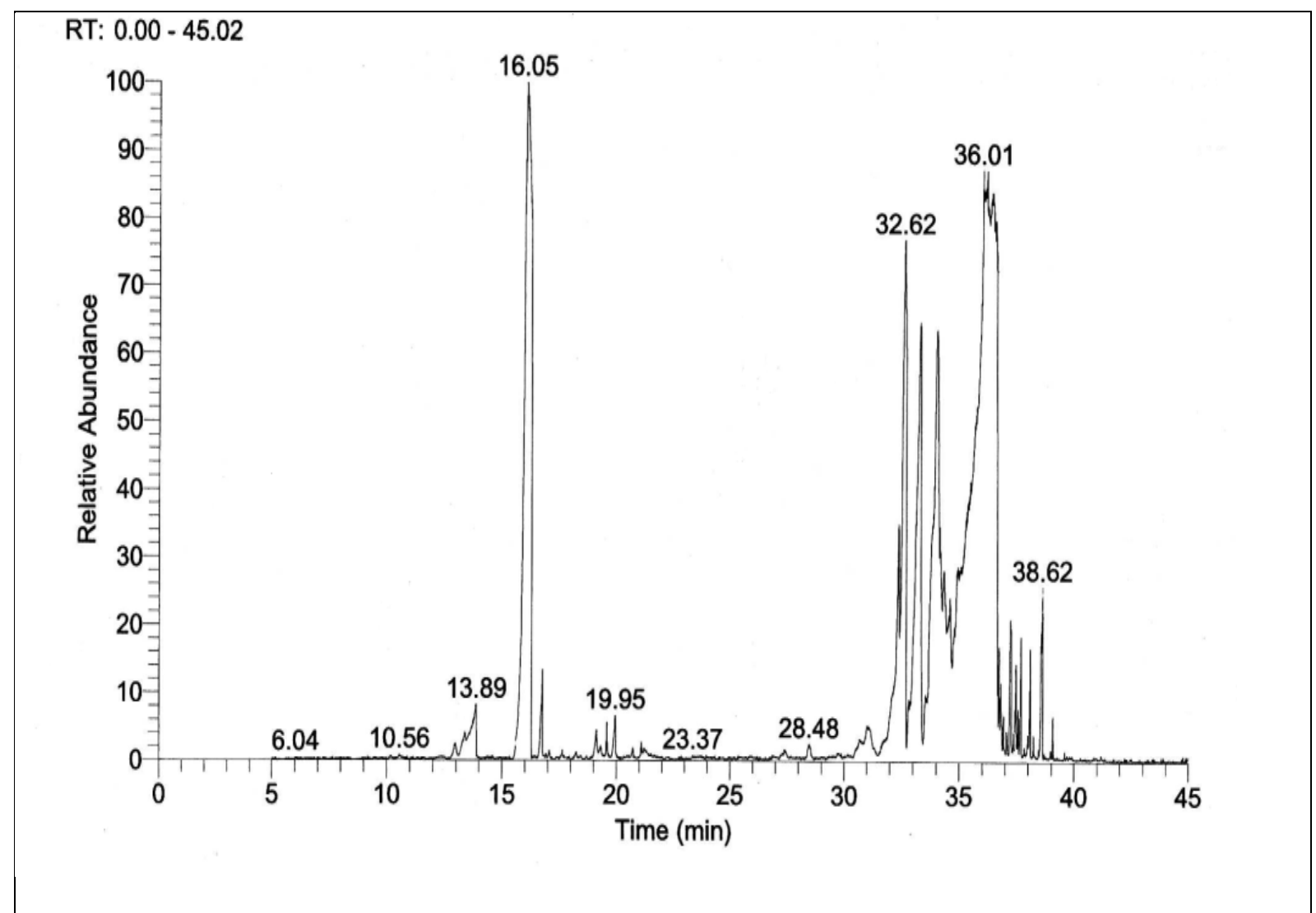

Figure 2. The chromatogram of GC/MS analysis of the essential oil of Eriocephalus africanus L. in vivo.

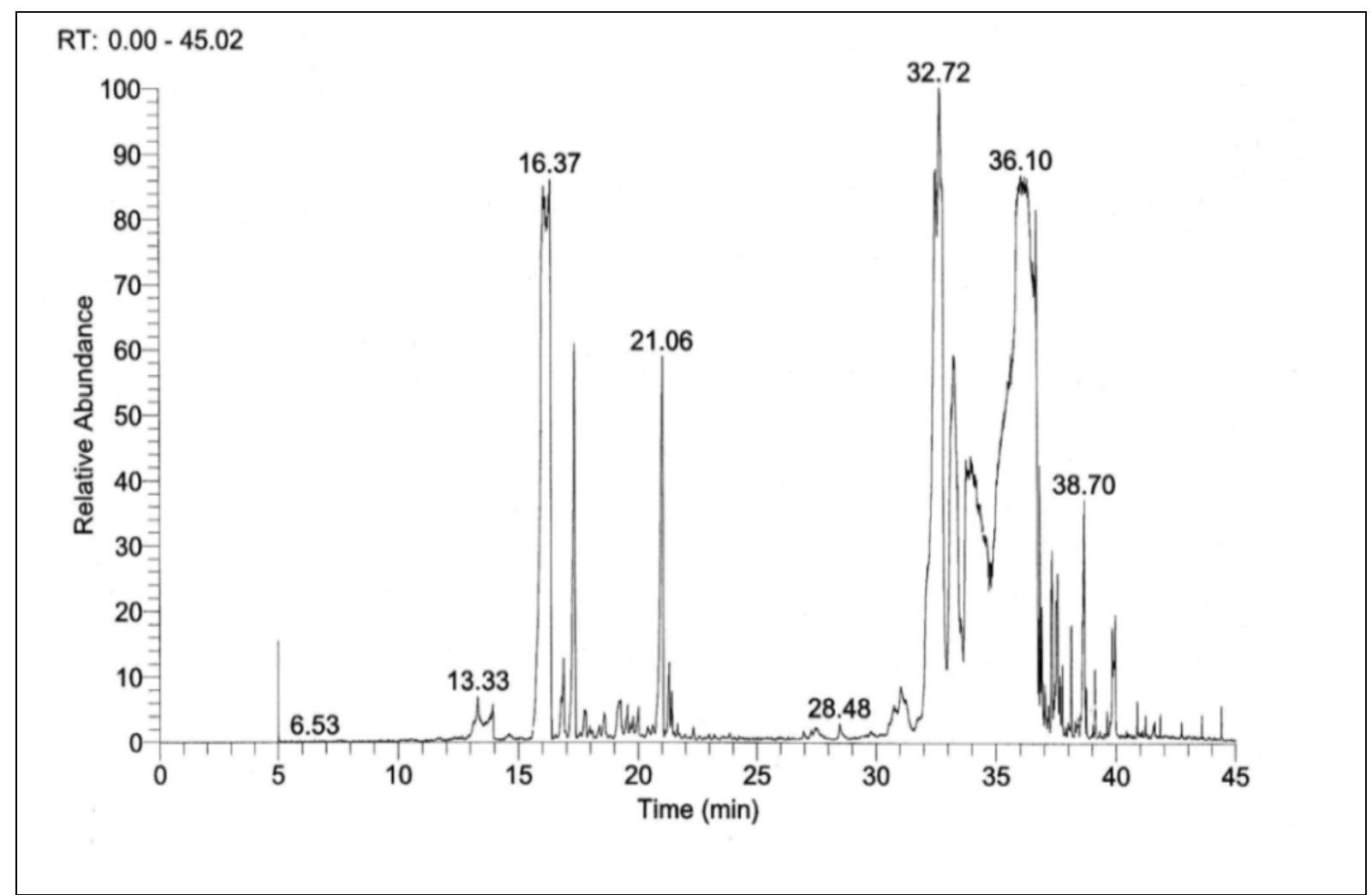

Figure 3. The chromatogram of GC/MS analysis of the essential oil of Eriocephalus africanus L. in vitro. 
aromadendrene epoxide $9.00 \%$ and $\beta$ eudesmol $5.97 \%$ were at in vivo plants as well as camphor $3.03 \%$, caryophyllene oxide $6.76 \%$ and eudesm-7(11)-en-4-ol 2.30\% at in vitro plantlets. However, the lowest percentage of compounds were artemisia ketone $17.10 \%$ at in vitro plantlets and also artemisia alcohol $1.52 \%$ and eudesm-7(11)en-4-ol $0.31 \%$ at in vivo plants as well as 1,8-cineole $\quad 0.33 \%$, camphor $0.26 \%$, caryophyllene oxide $2.85 \%$, globulol $2.17 \%$, allo-aromadendrene epoxide $0.51 \%$ and $\beta$ eudesmol $1.52 \%$ in field plants.

The three monoterpene hydrocarbons were ranged between about 4.95 at in vitro plantlets, $5.95 \%$ in field plants and $6.24 \%$ at in vivo plants, and seven sesquiterpene hydrocarbons with percentage of $16.60 \%$ at in vivo plants, ten representing $18.46 \%$ in field plants and seven with percentage of $18.67 \%$ at in vitro plantlets.

The highest percentage of the main constituents were $\alpha$-pinene $4.25 \%$, caryophyllene $<\mathrm{E}>2.50 \%$, $\alpha$-selinene $2.44 \%$ and selina-3,7(11)-diene $2.32 \%$ in field plants and also bicyclogermacrene $15.56 \%$ at in vitro plantlets. Whereas the lowest percentage of compounds were $\alpha$-pinene $3.10 \%$ and $\alpha$-selinene $0.47 \%$ at in vitro plantlets as well as caryophyllene $<\mathrm{E}>$ $0.31 \%$ and selina-3,7(11)-diene $0.34 \%$ at in vivo plants too bicyclogermacrene was $4.14 \%$ in field plants.

These results were in agreement with those of Jesionek et al. (2016) who observed that the essential oil content of the maternal plant, in vitro shoots and the regenerates of Rhododendron tomentosum Harmaja was determined by steam distillation and the obtained volatile fractions were analyzed by GC/MS. Some compounds like methyl everninate was present only in microshoots and regenerated plants' volatile fraction, while others were found solely in the ground material (for instance Ledol). Alloaromadendrene was the predominant constituent in the microshoots (4.50-9.20\%), while $\gamma$-terpineol (8.80-15.0\%), palustrol (11.50-15.70\%) and ledol (9.60-12.10\%) occurred in large quantities in maternal plants. Other compounds, like p-cymene was abundant in both in vitro cultures and maternal plants (4.60-5.20\%). Kulpa et al. (2018) obtained the essential oils by hydro distillation in Deryng and Clevenger apparatus from in vitro shoot cultures of Thymus vulgaris L. The essential oils were analyzed using gas chromatography-mass spectrometry (GC-MS). Analysis revealed the presence of 54 components represented mainly by oxygenated monoterpenes (56.81$57.28 \%$ ) and monoterpene hydrocarbons (31.90-33.72\%). Among the identified constituents, the most abundant were thymol (33.37-34.05\%), $\gamma$-terpinene (11.62-11.91\%), p-cymene (9.81-10.07\%), carvacrol (5.63$5.96 \%)$, carvacrol methyl ether (3.86-3.87\%) and linalool (3.16-3.36\%).

\section{REFERENCES}

Abd EL-Hamied, S.M.E. (2016). Phytochemical and biological studies of secondary metabolites of Artemisia abrotanum L. by tissue culture technique. M. Sc. Thesis, Genetic Engineering and Biotechnology Research Institute (G.E.B.R.I) Sadat City University.

Adams, R.P. (2004). Identification of Essential Oil Components by Gas Chromatography/Quadrupole Mass Spectroscopy. Allured Publishing Corporation 362 South Schmale Road, Carol Streat, Illinois 60188-2787 USA.

Al-Bari, M.A.A.; Sayeed, M.A. and Rahman, M.S. (2006). Characterization and antimicrobial activities of a phenolic acid derivative produced by Streptomyces bangladeshiensis: A novel species collected in Bangladesh. Res. J. Med. Sci., 1:77-81.

André, S.B.; Mongomake, K.; Modeste, K.K.; Edmond, K.K.; Tchoa, K.; Hilaire, K.T. and Justin, K.Y. (2015). Effects of plant growth regulators and 
carbohydrates on callus induction and proliferation from leaf explant of Lippia multiflora Moldenke (Verbenacea). Intl. J. Agri. Crop. Sci., 8(2):118-127.

Baiceanu, E.; Vlase, L.; Baiceanu, A.; Nanes, M.; Rusu, D. and Crisan, G. (2015). New polyphenols identified in Artemisiae abrotanium herb extract Molecules, 20(6):11063-11075.

Egyptian Pharmacopoeia (1984). General Organization for Government. Third Edition, Printing Office, Cairo.

El-Tarras, A.E.; Attia, O.A.; Wad, N.S.A.; Dessoky, E.L.D.S. and Mohamed, A.A. (2015). Genetic characterization and in vitro propagation of three medicinal plants collected from high altitude sites. International Journal of Biosciences, 6(6):37-46.

Gamborg, O.L.; Miller, R.A. and Ojima, K. (1968). Nutrient requirement of suspensions cultures of soybean root cells Exp. Cell. Res., 50:151-158.

Gomez, K.A. and Gomez, A.A. (1984). Statistical Procedure for Agricultural Research. $2^{\text {nd }}$ Ed, John Wiley and Sons Co., New York, USA., 680 pp.

Gopinath, B.; Gandhi, K. and Saravanan, S. (2014). In vitro propagation of an important medicinal plant Artemisia annua L. from axillary explants. Pelagia Research Library, Advanced in Applied Scienece Research, 5(1):254-258.

Jesionek, A.; Kokotkiewicz, A.; Wlodarska, P.; Filipowicz, N.; Bogdan, A.; Ochocka, R.; Szreniawa-Sztajnert, A.; Zabiegala, B.; Bucinski, A. and Luczkiewicz, M. (2016). In vitro propagation of Rhododendron tomentosum - an endangered essential oil bearing plant from Peatland. Acta Biologica Cracoviensia Series Botanica, 58(2):2943.

Kulpa, D.; Wesołowska, A. and Jadczak, P. (2018). Micropropagation and composition of essentials oils in garden thyme (Thymus vulgaris L.). Not. Bot. Horti. Agrobo, 46(2):525-532.

Labade, G.B.; Dale, N.S.; Umbarkar, R.B.; Gadhe, S.K. and Rote, Y.N. (2016). In vitro regeneration of Chrysanthemum (Chrysanthemum morifolium L.). International Journal of Information Research and Review, 3(11):3043-3045.

Liu, C.Z.; Murch, S.J.; Demerdash, M.E.L. and Saxena, P.K. (2003). Regeneration of the Egyptian medicinal plant Artemisia judaica. Plant Cell Reports, 21(6):525530.

Madzikane-Mlungwana, O.; Moyo, M.; Aremu, A.O.; Plíhalová, L.; Doležal, K.; Van Staden, J. and Finnie, J.F. (2017). Differential responses to isoprenoid, $N^{6}$ substituted aromatic cytokinins and indole-3-butyric acid in direct plant regeneration of Eriocephalus africanus. Plant Growth Regul., 82(1):103-110.

Merle, H.; Verdeguer, M.; Blazquez, M.A. and Boira, H. (2007). Chemical composition of the essential oils from Eriocephalus africanus L. var. africanus populations growing in Spain. Flavour Fragr. J., 22:461-464.

Monfort, L.E.F.; Bertolucci, S.K.V.; Lima, A.F.; de Carvalho, A.A.; Mohammed, A.; Blank, A.F. and Pinto, J.E.B.P. (2018). Effects of plant growth regulators, different culture media and strength MS on production of volatile fraction composition in shoot cultures of Ocimum basilicum. Industrial Crops \& Products, 116:231-239.

Nagesh, K.S.; Shanthamma, C. and Pullaiah, T. (2010). Somatic embryogenesis and pant regeneration from callus cultures of Curculigo orchioide, Gaertn. Indian. J. Biotechnology, 9:408-413.

Njenga, E.W. and Viljoen, A.M. (2006). In vitro 5-lipoxygenase inhibition and antioxidant activity of Eriocephalus L. (Asteraceae) species. South African J. Bot., 72:637-641. 
Njenga, E.W.; van Vuuren, S.F. and Viljoen, A. (2005). Antimicrobial activity of Eriocephalus L. species. South African J. Bot., 71: 81-87. Publishing, London.

Olszewski, N.; Sun, T. and Gubler, F. (2002). Gibberellin aignaling: biosynthesis, catabolism and response pathways. Plant Cell, (Supplement): 6180.

Pattino, B.G. (1981). Methods In Plant Tissue Culture. Dept. Hort. Agric, College, Maryland University., College Park, Maryland , USA., P: 8-29.

Salie, F.; Eagles, P.F. and Leng, H.M. (1996). Preliminary antimicrobial screening of four South African Asteraceae species. J. Ethnopharmacol., 52: 27-33.

Soliman, A.I.E. (2011). Tissue culture propagation of Rosmarinus officinalis L. and study the changes in its main active constituents. M.Sc. Thesis, Fac. Agric, Al-Azhar Univ., Cairo, Egypt.

Srivastava, J.; Lambert, J. and Vietmeyer, N. (1996). Medicinal plants: An expanding role in development. World Bank Technical Paper. No. 320: 112-114.

Verdeguer, M.; Blazquez, M.A. and Boira, H. (2009). Phytotoxic effects of Lantana camara, Eucalyptus camaldulensis and Eriocephalus africanus essential oils in weeds of Mediterranean summer crops. Biochem. Syst. Ecol., 37:362-369.

Yassien, M.Y.; EL-Zefzafy, M.M.; Dawoud, G.T.M.; Shahein, H.M. and Abd Elhameid, S.M.E. (2016). Effect of light intensity on some secondary metabolites of Artemisia abrotanum L. by tissue culture technique. European Journal of Pharmaceutical and Medical Research, 3(9):58-65.

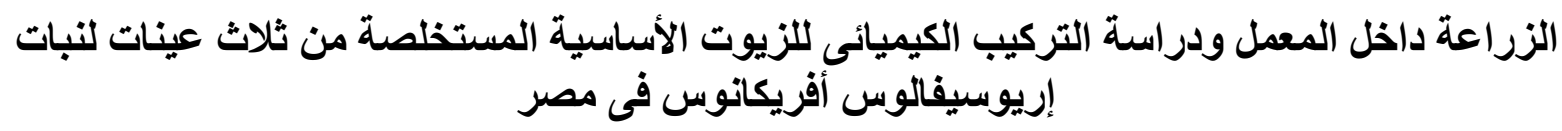

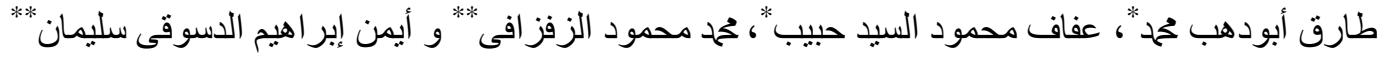

$$
\begin{aligned}
& \text { * قسم بساتين الزينة، كلية الزر اعة، جامعة القاهرة، الجيزة، مصر. } \\
& \text { ** قسم النباتات الطبية (زر اعة الأنسجة النباتية)، الهيئة القومية للرقابة والبة البحوث الدو ائية (نودكار )، الجيزة، مصر. }
\end{aligned}
$$

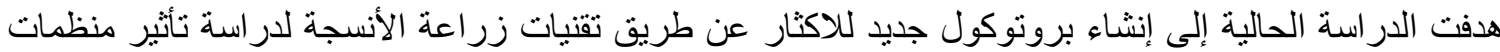

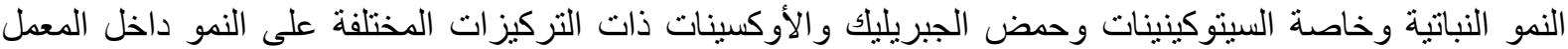

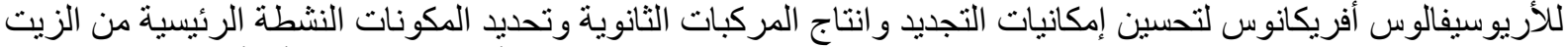

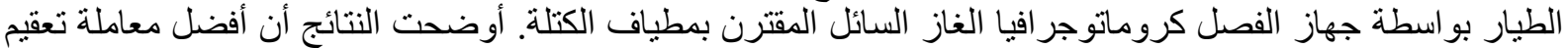
كانت غسل المنفصلات النباتية القمة النامية فى محلول كلوروكس

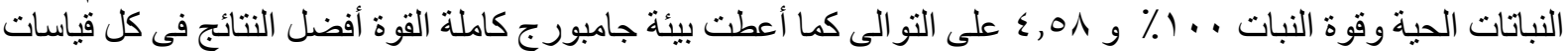

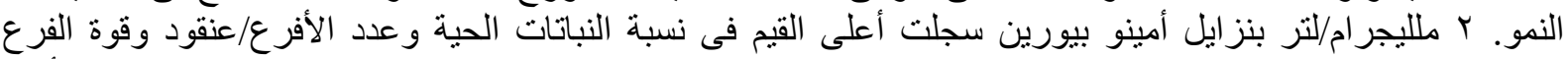

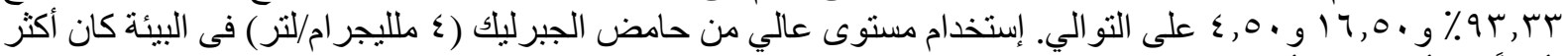

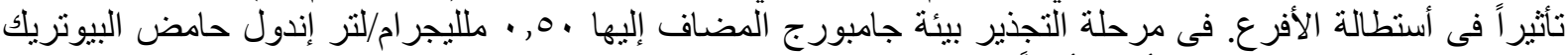

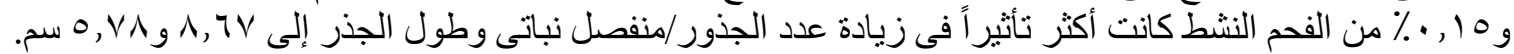

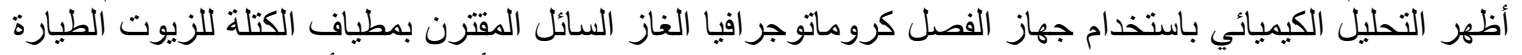

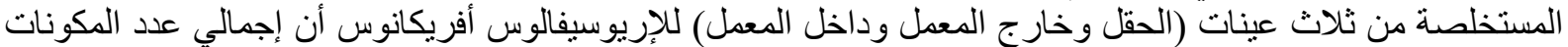

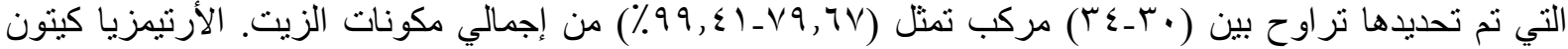

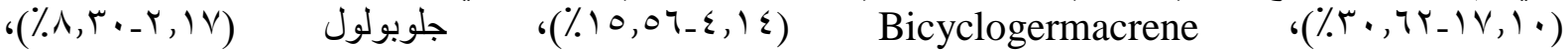
allo-Aromadendrene epoxide

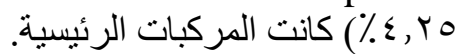

